\title{
The Study on Treatment of Nitrogen and Spacing with Variety Snowball
}

\author{
Arachana Singh, Shivam Singh, Shiwanand Pandey*, Vineet Singh, \\ Gaurav Singh Vishen and Avanish Kumar Singh \\ Udai Pratap Collage Varansi (An autonomous Institution), Varansi, \\ Uttar Pradesh-221002, India \\ *Corresponding author
}

\section{A B S T R A C T}

\begin{abstract}
Keywords
Nitrogen and Spacing,

Variety Snowball, minerals

Article Info

Accepted:

22 July 2018

Available Online:

10 August 2018

Field experiment regarding the effect of three levels of nitrogen control, lowest and highest dose per hectare which was supplied by means of urea and three levels of spacing that is $30 \mathrm{~cm}, 45 \mathrm{~cm}$ and $60 \mathrm{~cm}$ each were carried out and cauliflower seedlings were transplanted in the field on 28 December 2013 at the Vegetable Farm of Udai Pratap Autonomous College, Varanasi. Nitrogen application had significant effect for all the characters at all the stages of the cauliflower plant. Highest dose of nitrogen per hectare had significant effect on the height of the plant, fresh and dry weight of leaves and fresh and dry weight of curd at different stages of period. Spacing had also a significant effect on height of the plants, fresh and dry weights of curd at $60 \mathrm{~cm}$. spacing distance each significantly effective in above trials.
\end{abstract}

\section{Introduction}

Vegetable are vital sources of minerals, vitamins and carbohydrate dietary which play an important role in human nutrition. Apart from nutrition, they also contain a wide array of potential photochemical like anti carcinogenic and antioxidant. India ranks second in the production of vegetables after China. The cauliflower belongs to the family cruciferae and chromosome no. 18 botanically known as Brassica oleracea L. var. Botrytis is one of the important vegetable crops of India and it grown for white tender head or curd formed by the shortened flower parts. The name cauliflower goes by the Latin name caulis which means cabbage and floris which means flower said to be the native of South
Europe in the Mediterranean region (Thompson and Kelly, 1957.) The cauliflower is an important winter season vegetable crop in India. It originated in the island of Cyprus from where it moved to other areas like Syria, Turkey, Egypt, Italy, Spain and North Western Europe. (Boswell 1949). It was introduced to India in 1822 by a botanist James from kew Garden, London. It is used as a vegetable in curries and soups, and making for pickles. It may be cooked alone or mixed potatoes. It contains a good amount of vitamins B and a fair amount of proteins. The nutritive value of cauliflower is given according to (Premnath, 1976): Per $100 \mathrm{~g}$ of edible cauliflower contain (Moisture 90.80, Mineral 1.9, Carbohydrate 4g, Potassium 113mg, Fat 0.4g, Phosphorus $57 \mathrm{mg}$, Proteins $2.6 \mathrm{~g}$, Calcium 33mg, Calories 
30, Iron1.5, Vitamin A 51.1U, Vitamin C $56 \mathrm{mg}$.). There is an urgent and stressing need to augment production of vegetables in India if we want to have a healthy nation. Looking at the importance of this crop and future prospects of this cultivar, present investigation namely. The spacing in cauliflower cultivation is to obtain better curd yield without adversely affecting the quality was carried out during the year 2012-2013 in agro - climatic condition of Varanasi district is hopes that results of these investigations might prove some importance towards successful cultivation of cauliflower.

\section{Materials and Methods}

Materials and methods adopted in this experiment are described below- Randomized Block Design of Layout was followed taking into consideration each treatment as an independent character. Three levels of nitrogen and three levels of spacing with snowball were adopted. The nitrogen and spacing were major importance.

Thus the altogether 27 plots were prepared to accommodate 3 replications of different treatments with necessary path irrigation channel. In the experiment of present investigation, the treatment of nitrogen is levels of Nitrogen, $0 \mathrm{~kg}, 150 \mathrm{~kg}, 200 \mathrm{~kg}$ nitrogen per hectare and spacing with variety snowball were as distance between rows 30 $\mathrm{cm}, 45 \mathrm{~cm}, 60 \mathrm{~cm}$.

The observations were recorded to study the different characters of plants grown in different treatments in each replication. The following characters were studied:

\section{Height of plant (cm)}

The height of plants from bottom of levels of ground to the tips of leaves was measured at on interval of 20 days with the help of meter scale.

\section{Fresh weight of the plant (g)}

Three plants from each plot were selected and average weight of the plants was recorded, the intervals between observations were same as above.

\section{Number of leaves}

The leaves of selected sample account the total leaves and recorded the number.

\section{Fresh weight of head (g)}

The selected three heads removed and weighed on balance and recorded the weight in

\section{Dry weight of leaves (g)}

After taking the fresh weight of leaves dried in the electronic oven and weighed out on physical balance in $\mathrm{g}$.

\section{Dry weight of head (g)}

After taking the fresh weight of head dried in the electronic over and weighed out on physical balance in $\mathrm{g}$.

\section{Yield}

The total yield per sub-plot was recorded by weighing the whole harvested curd of each sub-plots. On this basis the yield per hectare were calculated in quintal.

\section{Statistical Analysis of Data}

The observations recorded on various characters were subjected to statistical analysis to find out the significance of the treatment on the characters under study. The experiment was conducted in randomized block design. The sum of squares and the mean sum of squares for the various treatment 
effects as well as replication were calculated in usual way.

\section{Results and Discussion}

Very interesting results were obtained when the effect of levels of nitrogen on various growth characters was studies. Untreated plant character with regard to growth was taken as control and the comparison of the variation in the growth characters of the treated plant was made to find out the significance effects.

\section{Height of plant}

Height of the plant, were significantly affected by 150 and $200 \mathrm{~kg}$ nitrogen per hectare at all the stages of life cycle. At 20 days stage 200 $\mathrm{kg}$ per hectare nitrogen was effective a very high degree to cause an increase of height of the plant $40.50 \mathrm{~cm}$, under $150 \mathrm{~kg}$ nitrogen per hectare the plant height $35.72 \mathrm{~cm}$, when nitrogen was not applied the plant height $30.41 \mathrm{~cm}$ were observed. At 40 day stage, the plant height was $55.11 \mathrm{~cm}$ observed under $200 \mathrm{~kg}$ nitrogen level, under $150 \mathrm{~kg}$ nitrogen per hectare the plant height $47.71 \mathrm{~cm}$, the plant height $42.94 \mathrm{~cm}$ were observed under control condition. At 60 day stage the plant height was $60.31 \mathrm{~cm}$ observed under $200 \mathrm{~kg}$ nitrogen level, under $150 \mathrm{~kg}$ nitrogen per hectare the plant height $56.85 \mathrm{~cm}$, when nitrogen was not applied the plant height $43.80 \mathrm{~cm}$ were observed. At 80 days stage also gave very good performance for the height of plant $61.18 \mathrm{~cm}$ were observed under $200 \mathrm{~kg}$, also gave very good results for the height of plant $58.81 \mathrm{~cm}$ at $150 \mathrm{~kg}$, when nitrogen was not applied the plant height $46.82 \mathrm{~cm}$, were observed. The effect of different levels of nitrogen at 20, 40, 60 and 80 days stages on height of plant were found highly significant at $1 \%$ level of signification (table-1). This height increased mainly due to rapid cell division and cell elongation in the meristematic regions. Plant growth with higher levels of protein and carbohydrate. These two compounds when present in high amounts in meristematicregions, induce rapid cell division and greater enlargement of the cells which ultimately result in increased height of the plant. In cauliflower, Srivastava (1958) and Choudhary (1961) have found increase in height with increasing nitrogen supply.

\section{Fresh weight of the plant (g)}

At 20 days stage $200 \mathrm{~kg}$ per hectare nitrogen was effective a very high degree to cause an increase of fresh weight of plant $17.56 \mathrm{~g}$, $150 \mathrm{~kg}$, per hectare nitrogen was effective a very high degree to cause an increase of fresh weight of plant $15.14 \mathrm{~kg}$ when nitrogen was not applied fresh weight of the plant $13.71 \mathrm{~g}$ were observed. At 40 days stage $200 \mathrm{~kg}$ per hectare nitrogen was effective a very high degree to cause an increase was effective a very high degree to cause an increase of fresh weight of plant $139.39 \mathrm{~g}$ when nitrogen was not applied fresh weight of the plant $73.43 \mathrm{~g}$ were obtained. At 60 days stage $200 \mathrm{~kg}$ per hectare nitrogen was effective a very high degree to cause an increase of fresh weight of plant $363.65 \mathrm{~g}, 150 \mathrm{~kg}$ per hectare nitrogen was effective a very high degree to cause an increase of fresh weight of plant $352.30 \mathrm{~g}$. When nitrogen was not applied fresh weight of the plant $267.06 \mathrm{~g}$ were obtained. At 80 days stage $200 \mathrm{~kg}$ per hectare nitrogen was effective a very high degree to cause an increase of fresh weight of plant $450.26 \mathrm{~g}$ this is a very good performance. $150 \mathrm{~kg}$ per hectare nitrogen was effective a very high degree to cause an increase of fresh weight of plant $364.18 \mathrm{~g}$ when nitrogen was not applied fresh weight of the plant $289.68 \mathrm{~g}$ were obtained. The fresh weight of plants was found highly significant (table-2). Nitrogen is central determinant of leaf photosynthetic capacity and yield. Its availability increases leaf water potential wall expansion properties 
of growing tissue which ultimately result in increased fresh weight of plant. This was also reported in cauliflower by (Lal and Subbarao, 1960; Crane and Steward, 1962) Ram and Sharma (1969).

\section{Number of leaves}

At 20 days stage $200 \mathrm{~kg}$ per hectare nitrogen was effective a very high degree to cause an increase of number of leaves $20.88,150 \mathrm{~kg}$ per hectare nitrogen was effective a very high degree to cause an increase of number of leaves 16.96, when nitrogen was not applied number of the leaves 13.08, when nitrogen was not applied number of the leaves 22.36, were obtained. At 60 days stage $200 \mathrm{~kg}$ per hectare nitrogen was effective a very high degree to cause an increase of number of leaves 33.11, at 60 days stage, $150 \mathrm{~kg}$ per hectare nitrogen was effective a very high degree to cause an increase of number of leaves 30.00, when nitrogen was no applied number of the leaves 26.72, were obtained At 80 days stage $200 \mathrm{~kg}$ per hectare nitrogen was effective a very high degree to cause an increase number of leaves $38.19 \mathrm{~g}$ this is very good performance. When nitrogen was not applied number of the leaves 33.31, were obtained.

The fresh weight of plants were found highly significant. (Table-3) This was also reported by Ram and Sharma (1969). Deficiency of nitrogen resulted reduced fresh weigh of constituent organs and whole plant (Lal and Subbarao, 1960; Crane and Steward, 1962). When the leaf number are less and size is small due to deficiency of nitrogen, results in less growth of cauliflower, this less growth obviously due to less meristematic activity.

\section{Fresh weight of head}

At 60 days stage $200 \mathrm{~kg}$ per hectare nitrogen was effective a very high degree to cause an increase of fresh weight of head $338.22 \mathrm{~g}$, $150 \mathrm{~kg}$ high degree to cause an increase of fresh weight of head $338.22 \mathrm{~g}, 150 \mathrm{~kg}$ per hectare nitrogen was effective a very high degree to cause an increase of fresh weight of head $237.08 \mathrm{~g}$, the values were recorded for the fresh weight of head are $168.68 \mathrm{~g}$ under control condition. At 80 days stage $200 \mathrm{~kg}$ per hectare nitrogen was effective a very high degree to cause an increase of fresh weight of head $576.33 \mathrm{~g}, 150 \mathrm{~kg}$ per hectare nitrogen was effective a very high degree to cause an increase of fresh weight of head $368.89 \mathrm{~g}$, the result of the fresh weight of curd $255.14 \mathrm{~g}$ were obtained in the absence of nitrogen. The fresh weight of head was found highly significant (table-4).Higher dose of nutrients enhanced synthesis and accumulation of food thereby resulted in higher head weight. The increased application of nutrient levels increases the growth parameters which might have synthesized more plant metabolites. These results are corroborated with those obtained by Kumar and Sahu (2013), similar result was also reported White and Forbes (1976).

\section{Dry weight of leaves}

At 20 days stage $200 \mathrm{~kg}$ per hectare nitrogen was effective a very high degree to cause an increase of dry weight of leaves $2.03 \mathrm{~g}$ at 20 days stage, $150 \mathrm{~kg}$ per hectare nitrogen was effective a very high degree to cause an increase of dry weight of leaves $1.73 \mathrm{~g}$ when nitrogen was not applied dry weight of the leaves. $1.40 \mathrm{~g}$ were obtained. At 40 days stage, $200 \mathrm{~kg}$ per hectare nitrogen was effective a very high degree to cause an increase of dry weight of leaves $13.69 \mathrm{~g}, 150 \mathrm{~kg}$ per hectare nitrogen was effective a very high degree to cause an increase of dry weight of leaves $11.37 \mathrm{~g}$, when nitrogen was not applied dry weight of the leaves $6.12 \mathrm{~g}$ were obtained. Similarly the constituent organs are greatly influenced by the nitrogen application. 
Table.1 Height of plant of cauliflower as affected by various level of nitrogen $\left(\mathrm{N}_{0}=\mathrm{kg} \mathrm{N} / \mathrm{ha}\right.$, $\mathrm{N}_{1}=150 \mathrm{~kg}, \mathrm{~N}_{2}-200 \mathrm{~kg} \mathrm{~N} / \mathrm{ha}$ )

\begin{tabular}{|c|c|c|c|c|c|c|}
\hline \multirow{2}{*}{$\begin{array}{l}\text { Age in } \\
\text { days }\end{array}$} & \multirow{2}{*}{$\begin{array}{l}\text { Nitrogen } \\
\text { (kg.) }\end{array}$} & \multicolumn{3}{|c|}{ Distance between rows $(\mathrm{cm})$} & \multirow[t]{2}{*}{ Mean } & \multirow[t]{2}{*}{ C.D. at $5 \%$} \\
\hline & & $\mathrm{S}_{1}$ & $\mathrm{~S}_{2}$ & $\mathrm{~S}_{3}$ & & \\
\hline \multirow{4}{*}{20} & $\mathrm{~N}_{0}$ & 28.62 & 30.03 & 32.59 & 30.41 & $\mathrm{~N} \& S=0.037$ \\
\hline & $\mathrm{N}_{1}$ & 34.03 & 35.82 & 37.30 & 35.72 & $\mathrm{NXS}=0.029$ \\
\hline & $\mathrm{N}_{2}$ & 38.05 & 40.15 & 43.30 & 40.50 & \\
\hline & Mean & 33.57 & 35.33 & 37.73 & & \\
\hline \multirow{4}{*}{40} & $\mathrm{~N}_{0}$ & 41.34 & 42.53 & 44.94 & 42.94 & $\mathrm{~N} \& S=0.018$ \\
\hline & $\mathrm{N}_{1}$ & 46.64 & 47.66 & 48.83 & 47.71 & $\mathrm{NXS}=0.031$ \\
\hline & $\mathrm{N}_{2}$ & 52.67 & 55.24 & 57.43 & 55.11 & \\
\hline & Mean & 46.88 & 48.48 & 50.40 & & \\
\hline \multirow{4}{*}{60} & $\mathrm{~N}_{0}$ & 40.64 & 42.91 & 47.85 & 43.80 & $\mathrm{~N} \& S=0.0365$ \\
\hline & $\mathrm{N}_{1}$ & 55.02 & 56.71 & 58.83 & 56.85 & $\mathrm{NXS}=0.632$ \\
\hline & $\mathrm{N}_{2}$ & 58.08 & 61.03 & 61.86 & 60.31 & \\
\hline & Mean & 51.23 & 53.55 & 56.18 & & \\
\hline \multirow{4}{*}{80} & $\mathrm{~N}_{0}$ & 44.73 & 45.96 & 49.77 & 46.82 & $\mathrm{~N} \& S=0.0365$ \\
\hline & $\mathrm{N}_{1}$ & 57.97 & 58.66 & 59.80 & 58.81 & $\mathrm{NXS}=0.0632$ \\
\hline & $\mathrm{N}_{2}$ & 59.02 & 61.66 & 62.87 & 61.18 & \\
\hline & Mean & 53.91 & 55.43 & 57.48 & & \\
\hline
\end{tabular}

Table.2 Fresh weight of plant of cauliflower as affected by level of nitrogen $\left(\mathrm{N}_{0}=\mathrm{kg} \mathrm{N} / \mathrm{ha}\right.$, $\mathrm{N}_{1}=150 \mathrm{~kg}, \mathrm{~N}_{2}-200 \mathrm{~kg} \mathrm{~N} / \mathrm{ha}$.)

\begin{tabular}{|c|c|c|c|c|c|c|}
\hline \multirow{2}{*}{$\begin{array}{l}\text { Age in } \\
\text { days }\end{array}$} & \multirow{2}{*}{$\begin{array}{l}\text { Nitrogen } \\
\text { (kg.) }\end{array}$} & \multicolumn{3}{|c|}{ Distance between rows (cm) } & \multirow[t]{2}{*}{ Mean } & \multirow[t]{2}{*}{ C.D. at $5 \%$} \\
\hline & & $\mathrm{S}_{1}$ & $\mathrm{~S}_{2}$ & $\mathrm{~S}_{3}$ & & \\
\hline \multirow[t]{4}{*}{20} & $\mathrm{~N}_{0}$ & 12.54 & 14.74 & 13.86 & 13.71 & $\mathrm{~N} \& \mathrm{~S}=0.122$ \\
\hline & $\mathrm{N}_{1}$ & 12.53 & 16.83 & 16.35 & 15.14 & $\mathrm{NXS}=0.212$ \\
\hline & $\mathrm{N}_{2}$ & 15.53 & 18.73 & 18.62 & 17.56 & \\
\hline & Mean & 13.37 & 16.77 & 16.28 & & \\
\hline \multirow[t]{4}{*}{40} & $\mathrm{~N}_{0}$ & 64.94 & 68.74 & 86.62 & 73.43 & $\mathrm{~N} \& S=0.079$ \\
\hline & $\mathrm{N}_{1}$ & 132.72 & 137.83 & 147.63 & 139.39 & $\mathrm{NXS}=0.137$ \\
\hline & $\mathrm{N}_{2}$ & 135.83 & 152.81 & 184.83 & 157.82 & \\
\hline & Mean & 111.16 & 119.79 & 139.69 & & \\
\hline \multirow{4}{*}{60} & $\mathrm{~N}_{0}$ & 265.02 & 267.23 & 268.94 & 267.06 & $N \& S=0.049$ \\
\hline & $\mathrm{N}_{1}$ & 302.53 & 362.35 & 392.02 & 352.30 & $\mathrm{NXS}=0.087$ \\
\hline & $\mathrm{N}_{2}$ & 322.94 & 331.24 & 393.77 & 363.65 & \\
\hline & Mean & 296.83 & 320.27 & 344.91 & & \\
\hline \multirow[t]{4}{*}{80} & $\mathrm{~N}_{0}$ & 264.86 & 296.03 & 308.16 & 289.68 & $N \& S=0.035$ \\
\hline & $\mathrm{N}_{1}$ & 331.94 & 361.83 & 398.76 & 364.18 & $\mathrm{NXS}=0.61$ \\
\hline & $\mathrm{N}_{2}$ & 409.14 & 468.40 & 473.23 & 450.26 & \\
\hline & Mean & 335.31 & 375.42 & 393.38 & & \\
\hline
\end{tabular}


Table.3 Number of leaves of cauliflower plant as affected by levels of nitrogen $\left(\mathrm{N}_{0}=\mathrm{kg} \mathrm{N} / \mathrm{ha}\right.$, $\mathrm{N}_{1}=150 \mathrm{~kg}, \mathrm{~N}_{2}-200 \mathrm{~kg} \mathrm{~N} / \mathrm{ha}$.)

\begin{tabular}{|c|c|c|c|c|c|c|}
\hline \multirow{2}{*}{$\begin{array}{l}\text { Age in } \\
\text { days }\end{array}$} & \multirow{2}{*}{$\begin{array}{l}\text { Nitrogen } \\
\text { (kg.) }\end{array}$} & \multicolumn{3}{|c|}{ Distance between rows $(\mathrm{cm})$} & \multirow[t]{2}{*}{ Mean } & \multirow[t]{2}{*}{ C.D. at $5 \%$} \\
\hline & & $S_{1}$ & $\mathrm{~S}_{2}$ & $\mathrm{~S}_{3}$ & & \\
\hline \multirow{4}{*}{20} & $\mathrm{~N}_{0}$ & 11.82 & 12.29 & 14.42 & 13.08 & $\mathrm{~N} \& S=0.035$ \\
\hline & $\mathrm{N}_{1}$ & 15.84 & 17.14 & 17.89 & 16.96 & \multirow[t]{2}{*}{$\mathrm{NXS}=0.061$} \\
\hline & $\mathrm{N}_{2}$ & 19.32 & 21.12 & 22.19 & 20.88 & \\
\hline & Mean & 15.66 & 17.08 & 18.17 & & \\
\hline \multirow{4}{*}{40} & $\mathrm{~N}_{0}$ & 21.04 & 22.42 & 23.61 & 22.36 & $\mathrm{~N} \& \mathrm{~S}=0.083$ \\
\hline & $\mathrm{N}_{1}$ & 25.62 & 26.65 & 27.71 & 26.26 & $\mathrm{NXS}=0.144$ \\
\hline & $\mathrm{N}_{2}$ & 29.03 & 31.31 & 32.40 & 30.91 & \\
\hline & Mean & 25.23 & 26.79 & 27.91 & & \\
\hline \multirow{4}{*}{60} & $\mathrm{~N}_{0}$ & 25.24 & 26.37 & 28.54 & 26.72 & $\mathrm{~N} \& S=0.029$ \\
\hline & $\mathrm{N}_{1}$ & 28.83 & 30.03 & 31.14 & 30.00 & $\mathrm{NXS}=0.051$ \\
\hline & $\mathrm{N}_{2}$ & 31.71 & 32.97 & 34.64 & 33.11 & \\
\hline & Mean & 28.59 & 29.69 & 31.44 & & \\
\hline \multirow{4}{*}{80} & $\mathrm{~N}_{0}$ & 31.77 & 33.36 & 34.81 & 33.31 & $\mathrm{~N} \& \mathrm{~S}=0.039$ \\
\hline & $\mathrm{N}_{1}$ & 36.96 & 37.93 & 39.70 & 38.19 & $\mathrm{NXS}=0.67$ \\
\hline & $\mathrm{N}_{2}$ & 42.52 & 44.70 & 47.13 & 44.78 & \\
\hline & Mean & 37.08 & 38.66 & 40.55 & & \\
\hline
\end{tabular}

Table.4 Fresh weight of head cauliflower as affected by levels of nitrogen $\left(\mathrm{N}_{0}=\mathrm{kg} \mathrm{N} / \mathrm{ha}\right.$, $\mathrm{N}_{1}=150 \mathrm{~kg}, \mathrm{~N}_{2}-200 \mathrm{~kg} \mathrm{~N} / \mathrm{ha}$.)

\begin{tabular}{|c|c|c|c|c|c|c|}
\hline \multirow[t]{2}{*}{ Age in days } & \multirow{2}{*}{$\begin{array}{l}\text { Nitrogen } \\
\text { (kg.) }\end{array}$} & \multicolumn{3}{|c|}{ Distance between rows (cm) } & \multirow[t]{2}{*}{ Mean } & \multirow[t]{2}{*}{ C.D. at $5 \%$} \\
\hline & & $\mathrm{S}_{1}$ & $\mathrm{~S}_{2}$ & $\mathrm{~S}_{3}$ & & \\
\hline \multirow{4}{*}{60} & $\mathrm{~N}_{0}$ & 135.07 & 153.56 & 217.41 & 168.68 & $\mathrm{~N} \& \mathrm{~S}=0.042$ \\
\hline & $\mathrm{N}_{1}$ & 25.92 & 240.11 & 245.20 & 237.08 & \multirow{2}{*}{$\mathrm{NXS}=0.073$} \\
\hline & $\mathrm{N}_{2}$ & 315.11 & 315.13 & 384.41 & 338.22 & \\
\hline & Mean & 225.37 & 236.27 & 283.34 & & \\
\hline \multirow{4}{*}{80} & $\mathrm{~N}_{0}$ & 218.37 & 236.27 & 282.34 & 225.14 & $\mathrm{~N} \& S=0.035$ \\
\hline & $\mathrm{N}_{1}$ & 318.39 & 334.52 & 453.76 & 368.89 & $\mathrm{NXS}=0.061$ \\
\hline & $\mathrm{N}_{2}$ & 508.22 & 573.89 & 646.89 & 576.33 & \\
\hline & Mean & 348.39 & 382.27 & 469.71 & & \\
\hline
\end{tabular}


Table.5 Dry weight of leaves cauliflower as affected by levels of nitrogen $\left(\mathrm{N}_{0}=\mathrm{kg} \mathrm{N} / \mathrm{ha}\right.$, $\mathrm{N}_{1}=150 \mathrm{~kg}, \mathrm{~N}_{2}-200 \mathrm{~kg} \mathrm{~N} / \mathrm{ha}$ )

\begin{tabular}{|c|c|c|c|c|c|c|}
\hline \multirow[t]{2}{*}{ Age in days } & \multirow{2}{*}{$\begin{array}{l}\text { Nitrogen } \\
\text { (kg.) }\end{array}$} & \multicolumn{3}{|c|}{ Distance between rows $(\mathrm{cm})$} & \multirow[t]{2}{*}{ Mean } & \multirow[t]{2}{*}{ C.D. at $5 \%$} \\
\hline & & $\mathrm{S}_{1}$ & $\mathrm{~S}_{2}$ & $\mathrm{~S}_{3}$ & & \\
\hline \multirow{4}{*}{60} & $\mathrm{~N}_{0}$ & 135.07 & 153.56 & 217.41 & 168.68 & \multirow{3}{*}{$\begin{array}{l}\mathrm{N} \& S=0.042 \\
\mathrm{NXS}=0.073\end{array}$} \\
\hline & $\mathrm{N}_{1}$ & 25.92 & 240.11 & 245.20 & 237.08 & \\
\hline & $\mathrm{N}_{2}$ & 315.11 & 315.13 & 384.41 & 338.22 & \\
\hline & Mean & 225.37 & 236.27 & 283.34 & & \\
\hline \multirow{4}{*}{80} & $\mathrm{~N}_{0}$ & 218.37 & 236.27 & 282.34 & 225.14 & $\mathrm{~N} \& \mathrm{~S}=0.035$ \\
\hline & $\mathrm{N}_{1}$ & 318.39 & 334.52 & 453.76 & 368.89 & $\mathrm{NXS}=0.061$ \\
\hline & $\mathrm{N}_{2}$ & 508.22 & 573.89 & 646.89 & 576.33 & \\
\hline & Mean & 348.39 & 382.27 & 469.71 & & \\
\hline
\end{tabular}

\begin{tabular}{|c|c|c|c|c|c|c|}
\hline \multirow[t]{2}{*}{ Age in days } & \multirow{2}{*}{$\begin{array}{l}\text { Nitrogen } \\
\text { (kg.) }\end{array}$} & \multicolumn{3}{|c|}{ Distance between rows $(\mathrm{cm})$} & \multirow[t]{2}{*}{ Mean } & \multirow[t]{2}{*}{ C.D. at $5 \%$} \\
\hline & & $\mathrm{S}_{1}$ & $\mathrm{~S}_{2}$ & $\mathrm{~S}_{3}$ & & \\
\hline \multirow{4}{*}{60} & $\mathrm{~N}_{0}$ & 17.20 & 21.57 & 35.64 & 21.47 & \multirow{3}{*}{$\begin{array}{l}\mathrm{N} \& \mathrm{~S}=0.035 \\
\mathrm{NXS}=0.061\end{array}$} \\
\hline & $\mathrm{N}_{1}$ & 26.76 & 30.26 & 36.1 & 31.04 & \\
\hline & $\mathrm{N}_{2}$ & 40.53 & 45.91 & 49.71 & 45.38 & \\
\hline & Mean & 28.16 & 32.58 & 37.15 & & \\
\hline \multirow{4}{*}{80} & $\mathrm{~N}_{0}$ & 22.41 & 27.07 & 34.71 & 27.06 & $\mathrm{~N} \& S=0.034$ \\
\hline & $\mathrm{N}_{1}$ & 38.30 & 44.37 & 50.21 & 44.30 & $\mathrm{NXS}=0.059$ \\
\hline & $\mathrm{N}_{2}$ & 57.71 & 65.08 & 76.93 & 66.57 & \\
\hline & Mean & 39.47 & 45.71 & 52.96 & & \\
\hline
\end{tabular}

Table.7 Yield of plant of cauliflower as affected by level of nitrogen $\left(\mathrm{N}_{0}=\mathrm{kg} \mathrm{N} / \mathrm{ha}, \mathrm{N}_{1}=150 \mathrm{~kg}\right.$, $\mathrm{N}_{2}-200 \mathrm{~kg} \mathrm{~N} / \mathrm{ha}$ )

\begin{tabular}{|l|l|l|l|l|}
\hline S. No. & Treatments & No. of plant Per hact. & Weight $(\mathrm{kg} / \mathrm{ha})$ & $\begin{array}{l}\text { Yield per ha. } \\
\text { (Quintal) }\end{array}$ \\
\hline 1. & $\mathrm{~N}_{0} \mathrm{~S}_{1}$ & 87500 & 177.97 & 177.97 \\
\hline 2. & $\mathrm{~N}_{0} \mathrm{~S}_{2}$ & 62500 & 139.53 & 139.53 \\
\hline 3. & $\mathrm{~N}_{0} \mathrm{~S}_{3}$ & 50000 & 127.30 & 127.30 \\
\hline 4. & $\mathrm{~N}_{1} \mathrm{~S}_{1}$ & 87500 & 343.26 & 343.26 \\
\hline 5. & $\mathrm{~N}_{1} \mathrm{~S}_{2}$ & 62500 & 278.75 & 278.75 \\
\hline 6. & $\mathrm{~N}_{1} \mathrm{~S}_{3}$ & 50000 & 252.92 & 252.92 \\
\hline 7. & $\mathrm{~N}_{2} \mathrm{~S}_{1}$ & 87500 & 453.50 & 453.50 \\
\hline 8. & $\mathrm{~N}_{2} \mathrm{~S}_{2}$ & 62500 & 388.30 & 388.30 \\
\hline 9. & $\mathrm{~N}_{2} \mathrm{~S}_{3}$ & 50000 & 372.50 & 372.50 \\
\hline
\end{tabular}


Fig.1 Effect of various levels of $\mathrm{N}$ on the height of cauliflower plant

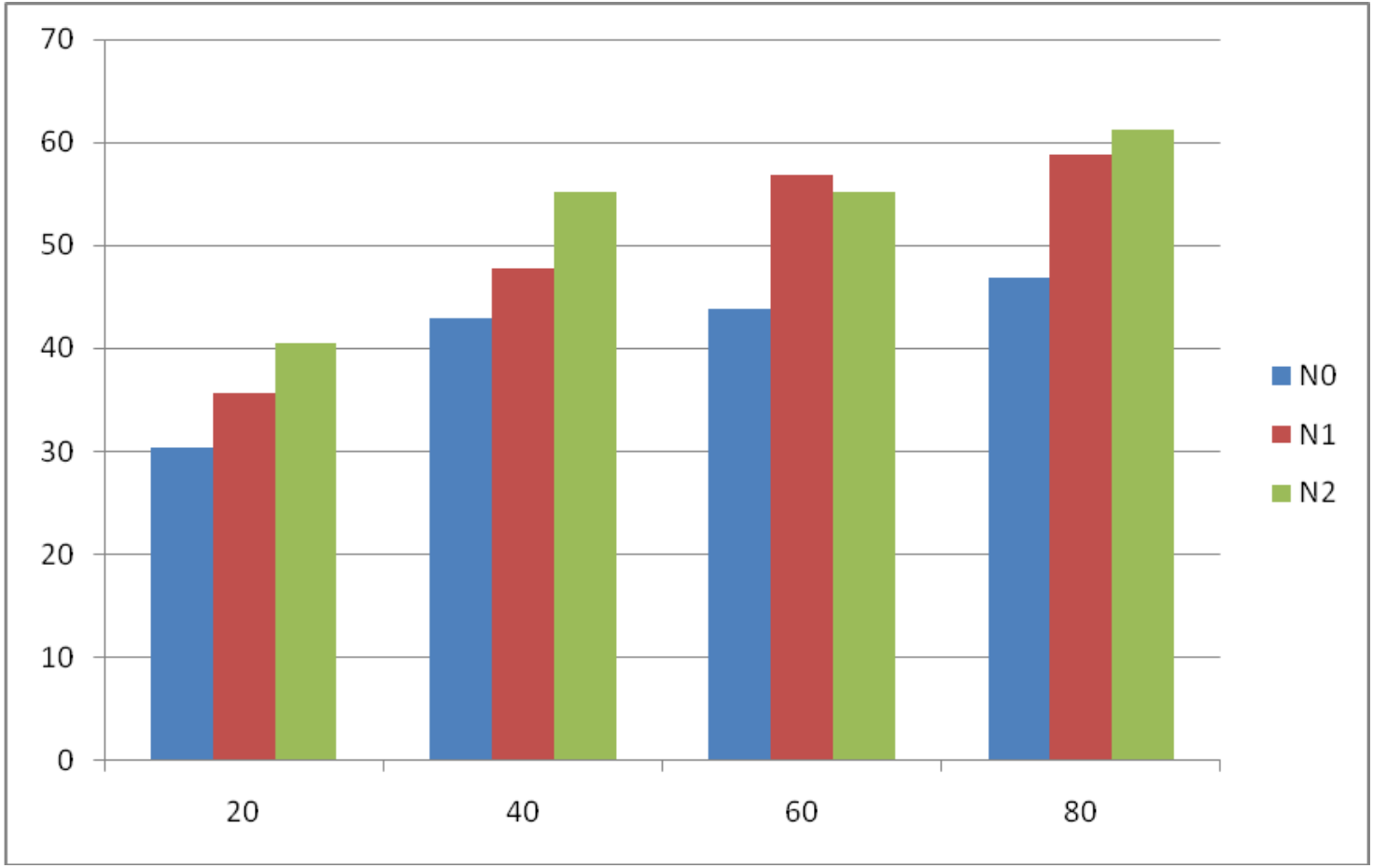

Fig.2 Effect of various levels of $\mathrm{N}$ on the fresh weight of cauliflower plant

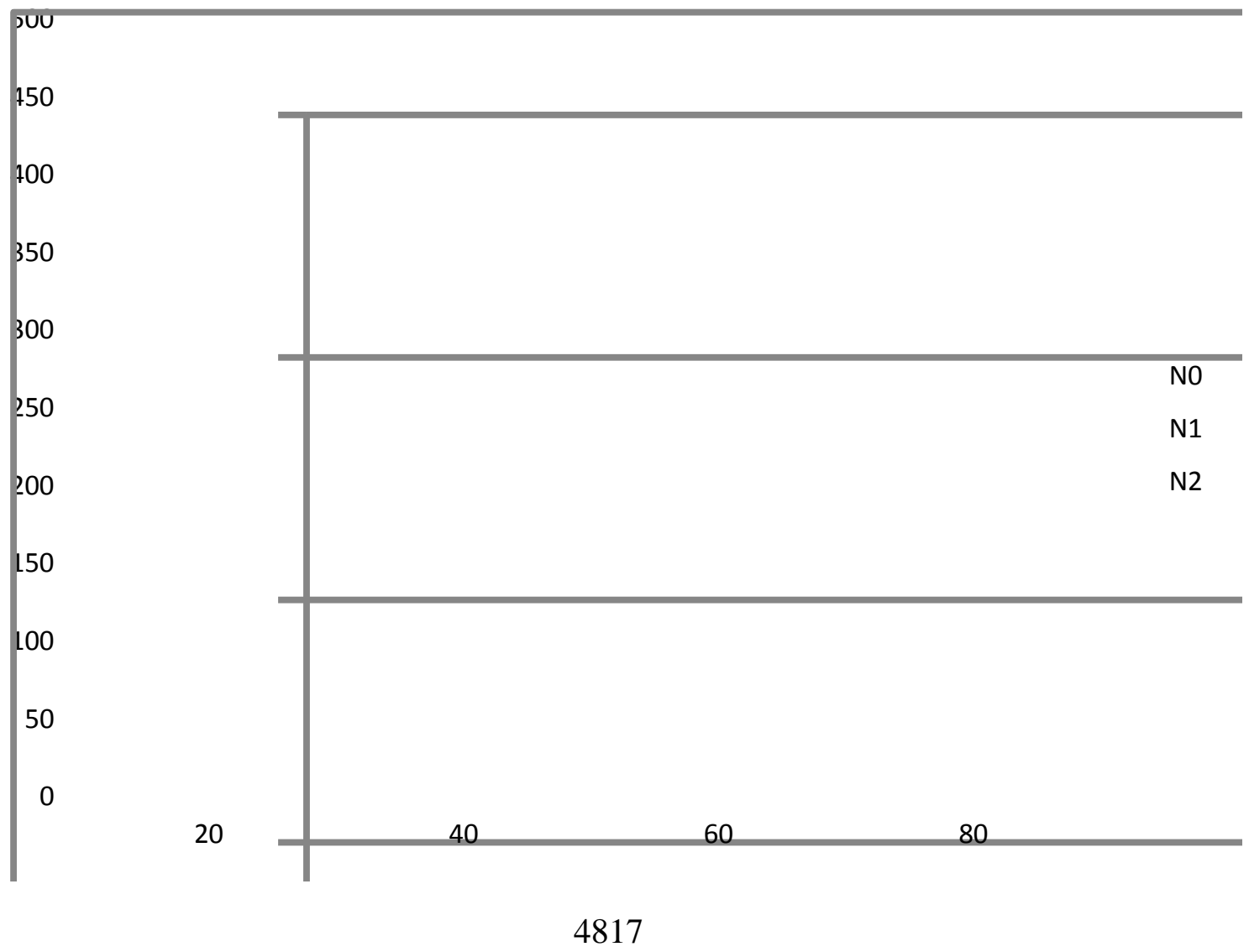


Fig.3 Effect of various levels of $\mathrm{N}$ and on the number of leaves per cauliflower plant

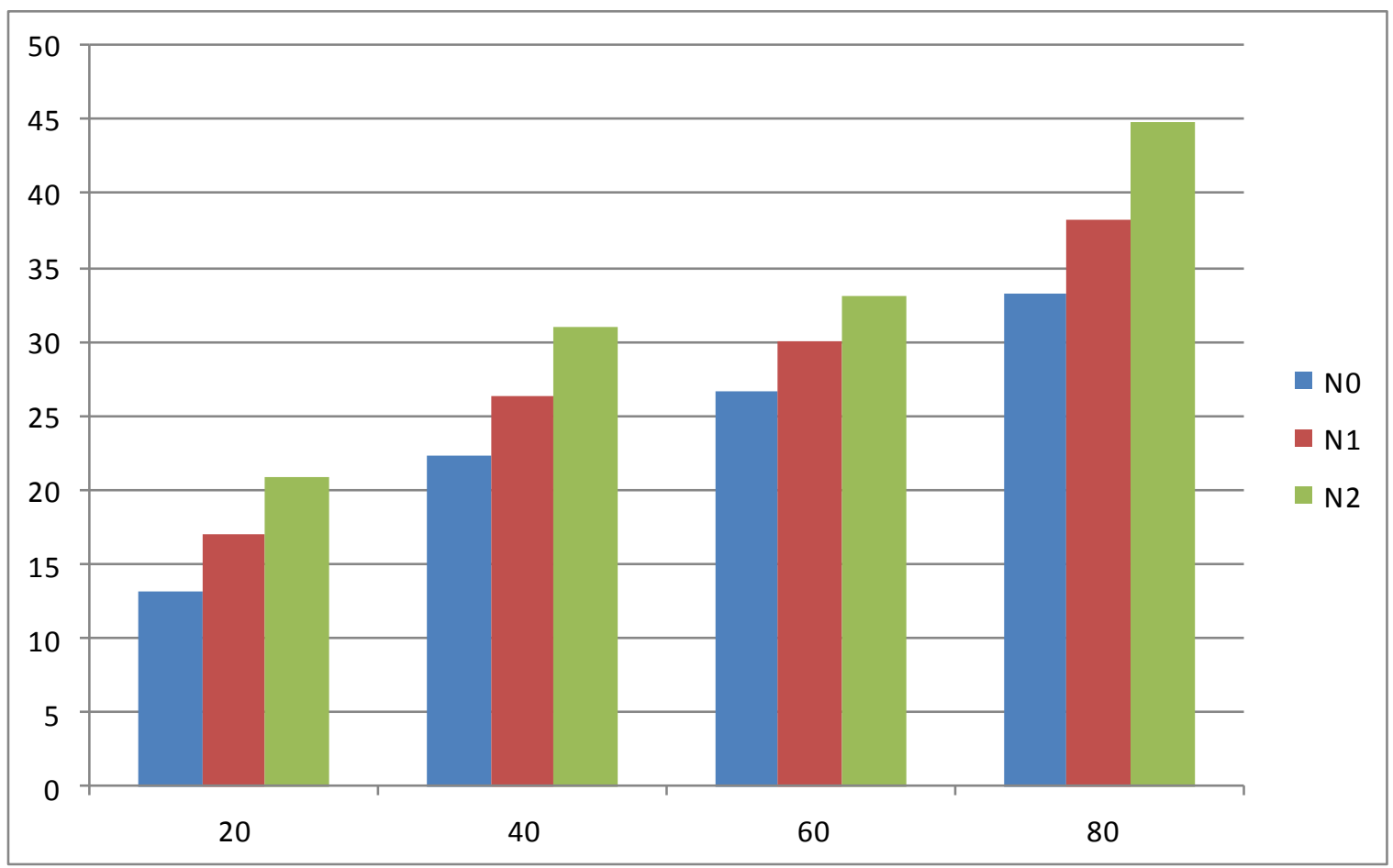

Fig.4 Effect of various levels of $\mathrm{N}$ and on the fresh weight of head of cauliflower plant.

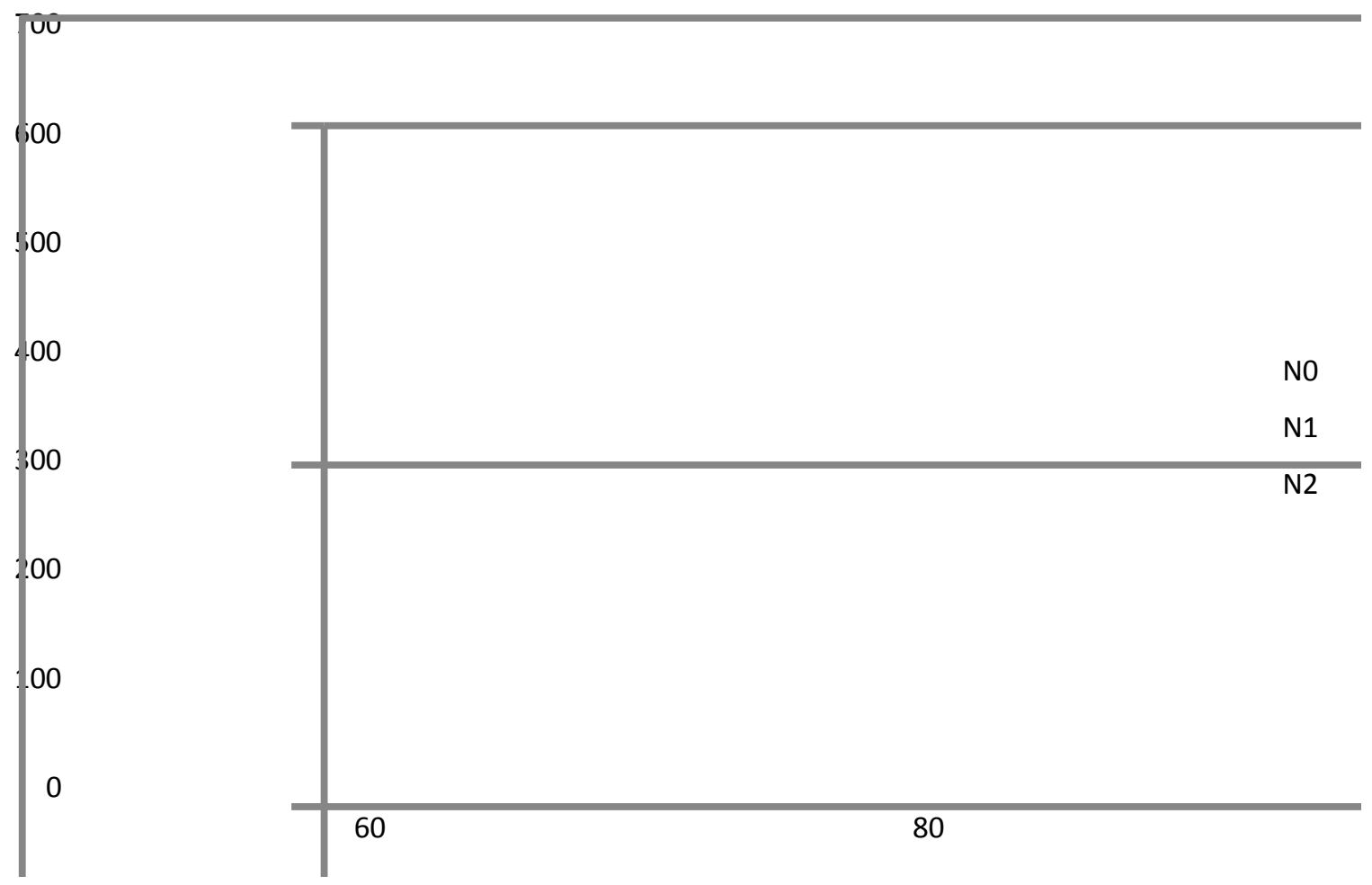


Fig.5 Effect of various levels of $\mathrm{N}$ on Dry weight of leaves of cauliflower plant

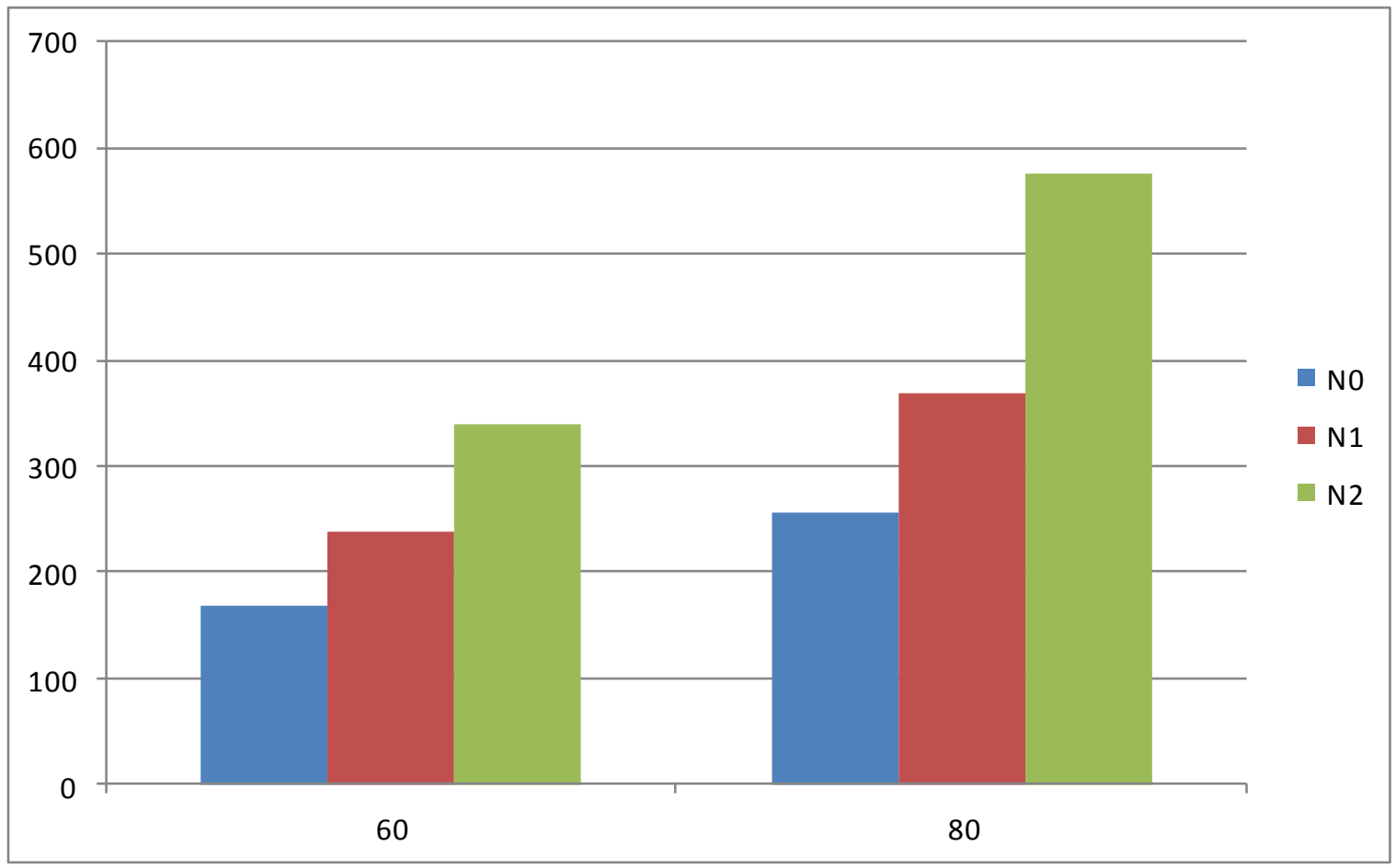

Fig.6 Effect of various levels of $\mathrm{N}$ on dry weight of head of cauliflower plant

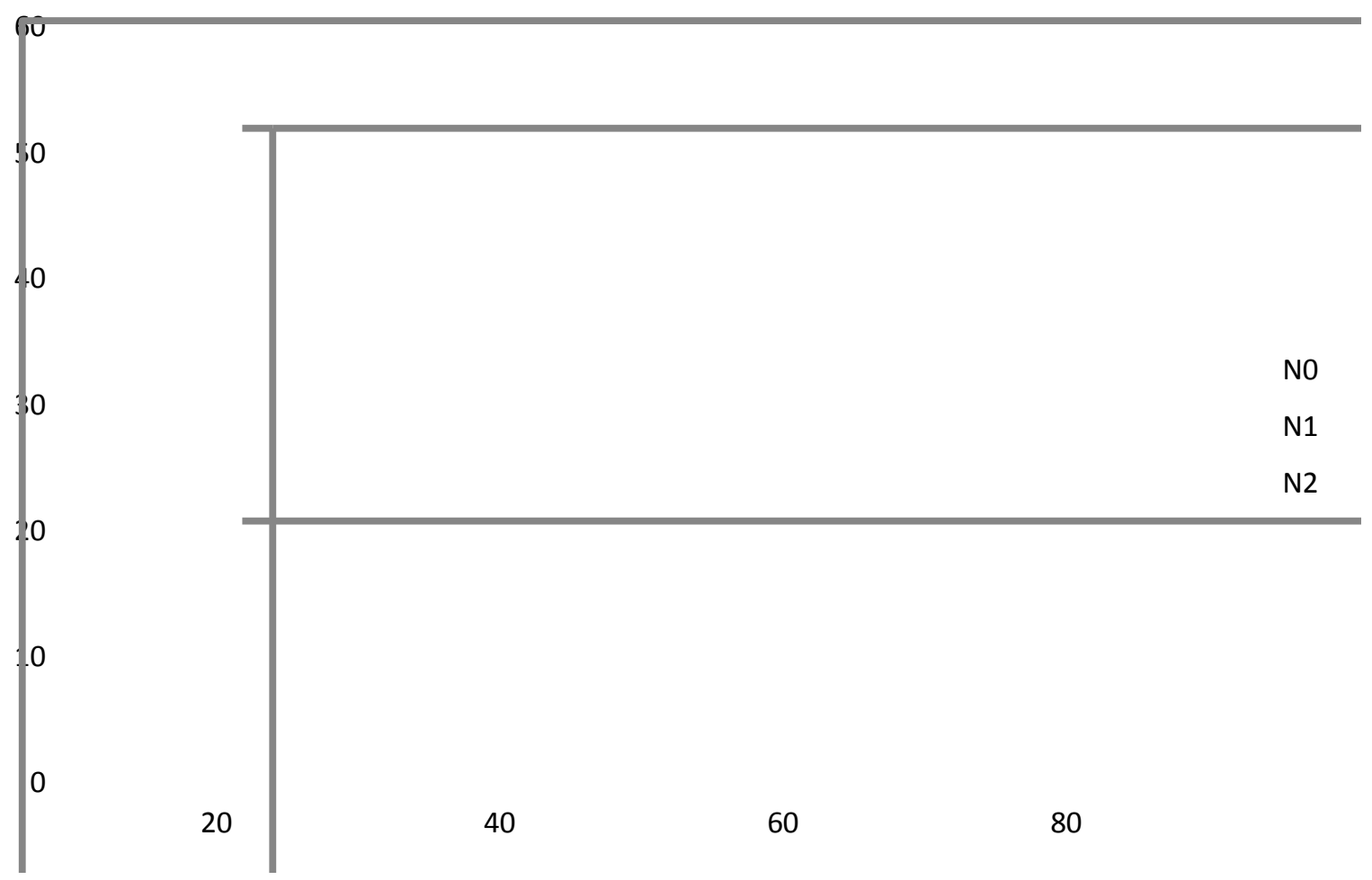


Fig.7 Effect of various levels of $\mathrm{N}$ on yield (q/ha) of cauliflower plant

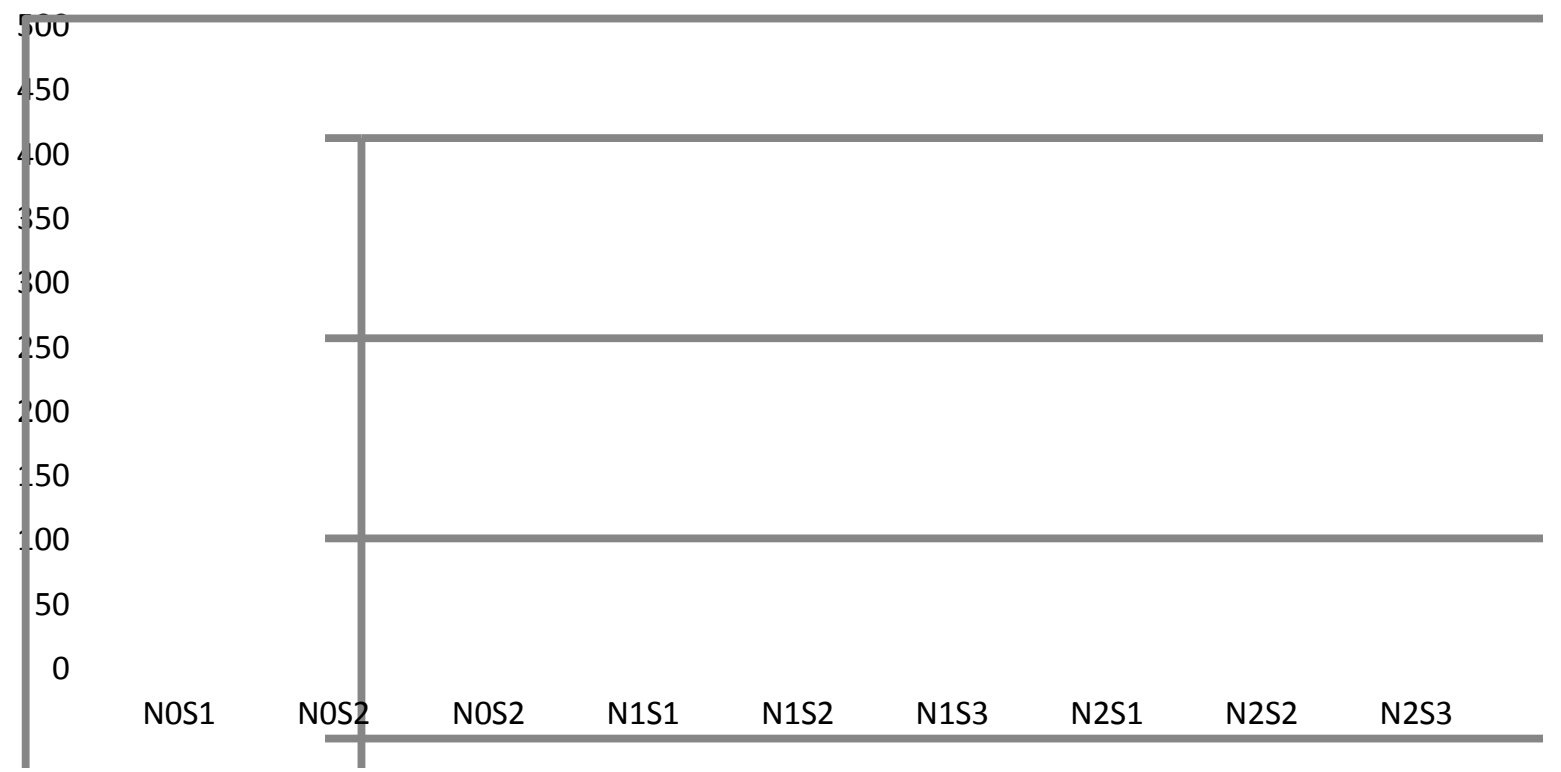

The highest dose of nitrogen i.e., $200 \mathrm{~kg}$ per hectare increased the dry weight of constituent organs over $150 \mathrm{~kg}$ per hectare and $0 \mathrm{~kg}$ per hectare (Table-5). We know the fact very well that nitrogen increases (Fig. 5) growth and thereby increase in dry matter accumulation. Explanation for above statement may be given that nitrogen increases the formation of new leaves and leaves help for synthesis of carbohydrates and other nitrogenous compounds which are a must of ultimately this gives more dry matter, These finding is supported by Mishra et al., (2014).

\section{Dry weight of head}

At 60 days stage, $200 \mathrm{~kg}$ per hectare nitrogen was effective a very high degree to cause an increase of dry weight of head $45.38 \mathrm{~g}, 150 \mathrm{~kg}$ per hectare nitrogen was effective a very high degree to cause an increase of dry weight of head $31.04 \mathrm{~g}$, when nitrogen was not applied dry weight of head $21.47 \mathrm{~kg}$ were obtained. At 80 days stage, $200 \mathrm{~kg}$ per hectare nitrogen was effective a very high degree to cause an increase of dry weight of head $66.57 \mathrm{~g}, 150 \mathrm{~kg}$ per hectare nitrogen was effective a very high degree to cause an increase of dry weight of head $44.30 \mathrm{~g}$, when nitrogen was not applied dry weight of head $27.06 \mathrm{~g}$ were obtained. The dry weight of leaves was found highly significant. (Table-6). These results are in agreement with the findings of Haque (2015) in cabbage, EI- Bassiony et al., (2014) in kohlrabi and Zaki et al., (2015) in broccoli.

\section{Yield}

The calculated values for yield in quintals per hectare were obtained for each treatment which is shown in (Table-7). The maximum yield per hectare 453.50 quintals were found under $\mathrm{N}_{2} \mathrm{~S}_{1}$ treatment $200 \mathrm{~kg}$ nitrogen levels at $30 \mathrm{~cm}$ distance. Caruso (1969) reported that the nitrogen was very effective specially when applied with phosphorus at the ratio of $120-140 \mathrm{~kg}$ per hectare. The effect of phosphorus was uncertain but application of nitrogen increased the yield and head size.

Nitrogen application had significant effect for all the characters at all the stages of the cauliflower plant. Highest dose of nitrogen 
per hectare had significant effect on the height of the plant, fresh and dry weight of leaves and fresh and dry weight of curd at different stages of period. Spacing had also a significant effect on height of the plants, fresh and dry weights of curd at $60 \mathrm{~cm}$. rows distance each significantly effective in above trials. The highest yield per hectare was obtained 453.50 quintals per hectares on treatment $200 \mathrm{~kg}$ nitrogen level, and at $30 \mathrm{~cm}$ distance. It clearly showed that there was spacing between rows but the yield per hectare was appreciably reduced as compared to closer spacing. Thus a spacing of $30 \mathrm{~cm}$ between rows gave the highest yield per hectare. Growth characters showed favourably the increasing tendency with increasing distance between rows.

\section{References}

Caruso, P. (1969): Manring in early Cauliflower experimental result obtained in Sicily, Reprint from Conclimic. Concimaz No. 9 pp: 3-15 Bib. 27 (Fresh and English Summaries).

Chaudhary, B.B. (1961): Effect of different doses of nitrogen phosphorus and potash on cauliflower, Thesis for M.Sc. (Ag.) Degree, IARI, New Delhi.

EI-Bassiony, A. M.; Fawzy, Z. F.; EI-Nemr, M. A. and $\mathrm{Li}, \mathrm{Y}$. (2014). Improvement of growth, yield and quality of two varieties of kohlrabi plants as affected by application of some bio stimulants. J. Agric. Res. 3(3): 491-498.

Haque, F. A.; Islam, N.; Islam, M.N.; Ullah, A. and Sarkar, M. D. (2015). Growth, yield and Profitability of cabbage (Brassica oleracia L.) as influenced by appliesd nitrogen and plant spacing. The agriculturist 13(1):35-45.

Kumar, Satish, Singh, J.P., Rajbeer, Ram, Nathi, Mohan, Braj, Kaushik, Himanshu and Kumar, Dinesh (2013). Influence of integrated nutrient management on growth and yield of cauliflower (Brassica oleracea var. botrytis L.) cv. NHB-1012. Internat. J. agric. Sci., 9(2): 747-749.

Mishra, S.P.; Tropathi, M.H. (2014): Effect of age of seedling and spacing on the growth, yield and other characters of cauliflower var-snowball-16. Progressive Horticulture, 17(2): 129-133.

Singh R, Chaurasia S N S and Singh S N (2006). Response of nutrient sources and spacing on growth and yield of broccoli (Brassica oleracea Varital icaplaenk) Veg. Sci. 33: 198- 200.

Srivastva, R.S.P. (1958): Effect of application of different doses of nitrogen phosphorus and molybdenum on cauliflower. Thesis for Assoc. IARI. Diploma.

Thompson, M.C. and Kelly, Williom C. (1957): Vegetable crop (book).McGraw Hill Publishing Company Ltd. Bombay, New Delhi, pp. 295-296.

White, J.M. and R.B. Forbes. (1976). Effect of spacing and fertilizer rates on cabbage yield and head weight. Proc. Fla. State Hort. Soc. 89: 118-120.

White, J.M.; Forbes, R.B. (1976): Effect of spacing and fertilizer rates on cabbage yield and head weight. Proceeding of the Florida, State Horticultural Society. 89: 118-120.

Zaki, M. F.; Saleh, S. A.; Tantawy, A. S. and EIDewiny, C., Y. (2015). Effect of different rates of potassium fertilizer on the growth, productivity and quality of some broccoli cultivars under new reclaimed soil conditions. Int. J. Chem. Tech. Res. 8(12): 28-39.

\section{How to cite this article:}

Arachana Singh, Shivam Singh, Shiwanand Pandey, Vineet Singh, Gaurav Singh Vishen and Avanish Kumar Singh. 2018. The Study on Treatment of Nitrogen and Spacing with Variety Snowball. Int.J.Curr.Microbiol.App.Sci. 7(08): 4810-4821.

doi: https://doi.org/10.20546/ijcmas.2018.708.506 